
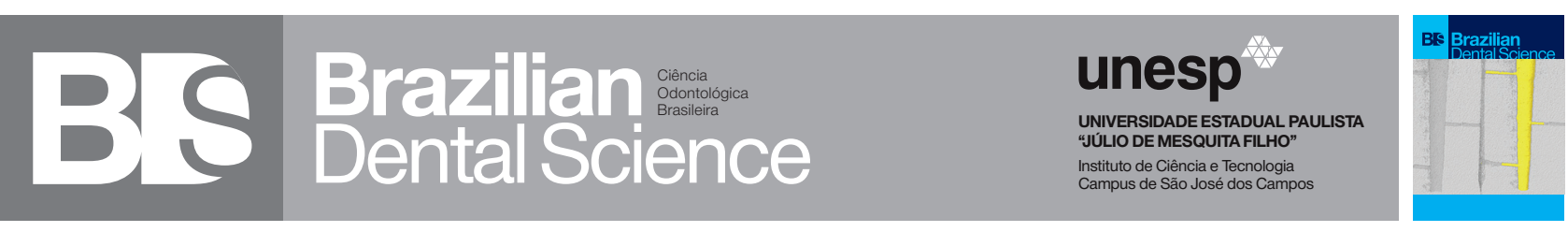

\title{
Interaction between photoactivators and adhesive systems used as modeling liquid on the degree of conversion of a composite for bleached teeth
}

Interação entre fotoativadores e sistemas adesivos usados como líquido modelador no grau de conversão de um compósito para dentes clareados

\begin{abstract}
Thiago Jonathan Silva dos SANTOS ${ }^{1}$, Ana Margarida dos Santos MELO ${ }^{1}$, Matheus Dantas TERTULINO ${ }^{1}$, Boniek Castillo Dutra BORGES ${ }^{1}$, Ademir Oliveira da SILVA ${ }^{2}$, Maria Cristina dos Santos MEDEIROS ${ }^{1}$.

1 - Department of Dentistry - Federal University of Rio Grande do Norte (UFRN) - Natal - RN - Brazil.

2 - Institute of Chemistry - Federal University of Rio Grande do Norte (UFRN) - Natal - RN - Brazil.
\end{abstract}

\begin{abstract}
Objective: This study analyzed the effect of two light emitting diodes (LEDs) on the degree of conversion (DC) of a composite resin for bleached teeth under the influence of adhesive systems used as modeling liquid. Material and Methods: A total of 60 samples of IPS Empress Direct resin (Ivoclar, Vivadent) in BL-L shade were made in a single increment and polymerized for 20 seconds. The treatments were: 1) Type of adhesive used as modeling liquid (Adper Single Bond 2; the bond component of Adper Scotchbond Multi-Purpose; or no adhesive systems used as modeling liquid were used in the control group); and 2) Type of LED (Bluephase, polywave; and Coltolux, monowave). The DC, percentage of monomers converted to polymer during polymerization, was evaluated using Fourier Transform Infrared Spectroscopy (FTIR) with 10 scans and wavenumber related to $1 / \lambda$ for observation of the peaks at 1608 and $1638 \mathrm{~cm}^{-1}$. Data were statistically analyzed by two-way analysis of variance (ANOVA) with Tukey's test $(\mathrm{p}<0.05)$. Results: There was no statistical difference between LEDs in comparison to the treatments ( $p>0.05)$. However, there was a statistically significant increase in the DC for the adhesive systems tested in comparison to the control group ( $\mathrm{p}<0.05$ ), with the highest values for Single Bond 2. Conclusion: It is concluded that the use of adhesives as modeling liquid of Empress Direct resin for bleached teeth shade increases the degree of conversion of the composite surface, and that curing with both kinds of LEDs does not interfere in this property.
\end{abstract}

\section{KEYWORDS}

Composite resins; Dentin-bonding agents; Surface properties.

\section{RESUMO}

Objetivo: Esse estudo analisou o efeito de dois diodos emissores de luz (LEDs) no grau de conversão (GC) de uma resina composta para dentes clareados sob a influência de sistemas adesivos usados como líquido modelador. Material e Métodos: Um total de 60 amostras da resina IPS Empress Direct (Ivoclar, Vivadent) na cor BL-L foram feitas em incremento único e polimerizadas por 20 segundos. Os tratamentos foram: 1) Tipo de adesivo usado como líquido modelador (Adper Single Bond 2; o componente "bond" do Adper Scotchbond Multi-Purpose; ou nenhum dos sistemas adesivos usados como líquido modelador foram utilizados no grupo controle); e 2) Tipo de LED (Bluephase, polifásico; e Coltolux, monofásico). O GC, percentual de monômeros convertidos em polímero durante a polimerização, foi avaliado usando Espectroscopia de Infravermelho com Transformada de Fourier (FTIR) com 10 varreduras e número de ondas relacionado de $1 / \lambda$ para a observação dos picos de 1608 e $1638 \mathrm{~cm}^{-1}$. Os dados foram analisados estatisticamente por análise de variância (ANOVA) a dois fatores com pós-teste de Tukey ( $\mathrm{p}<0,05)$. Resultados: Não houve diferença estatística entre os LEDs na comparação para os tratamentos ( $p>0,05)$. Entretanto, houve um aumento estatisticamente significativo no GC para os sistemas adesivos testados em comparação com o grupo controle $(p<0,05)$, com os maiores valores para o Single Bond 2. Conclusão: Conclui-se que o uso de adesivos como líquido modelador da resina Empress Direct para dentes clareados aumenta o grau de conversão de superfície dos compósitos e que a fotoativação com ambos os tipos de LEDs não interfere nessa propriedade.

\section{PALAVRAS-CHAVE}

Resinas compostas; Adesivos dentinários; Propriedades de superfície. 


\section{INTRODUCTION}

$\mathrm{T}$ he current demand for increasingly clear teeth has promoted the development of composites that enable restorations with optical characteristics which are more similar to natural teeth and have greaterlongevity [1]. For this, proper polymerization of composites is necessary and can be measured by Degree of Conversion (DC) analysis, a method that evaluates the amount of monomers converted to polymer during polymerization [2].

Therefore, the proper choice of light emitting diodes (LEDs) gives better physical properties [3], since it avoids a low DC which increases bacterial formation, monomer release, composite solubility, and staining susceptibility [4]; it also gives better color stability because aesthetic properties of the composite resins are intimately related to the optical light interaction with the restoration [5].

The most popular LEDs currently on the market are second and third generation, denoted monowave and polywave, respectively. However, despitemonowaveLEDsemittinghighlightintensity, they do not enable adequate polymerization of some photoinitiators and alternative co-initiators [6-8], thereby potentially causing problems in the polymerization reaction. Alternative photoinitiators such as (2,4,6-trimethylbenzoyl)diphenylphosphine oxide (TPO) and bis-alkyl phosphinic oxide (BAPO) have been replacing camphorquinone (CQ) in some composites to reduce the yellowing effect caused by CQ [9]. Thus, polywave LEDs were introduced in an attempt to find a proper LED for these alternative co-initiators [10].

Another aspect related to the restorative technique consists in controlling the stickiness of composites provided by the presence of some monomers such as bisphenol-A glycidyl dimethacrylate (Bis-GMA) [11], which makes restoration modeling difficult [12]. In an attempt to minimize this effect, clinicians have used some products such as alcohol and adhesive systems on spatulas and brushes during the incremental technique $[13,14]$.

Some studies have demonstrated that these modeling liquids did not change physical properties such as cohesive strength [13-14] or even improve the physical stability of these composites [15] when used between layers. However, it has been shown that some adhesives used as modeling liquid have changed the physical properties on the surface of resins in shade A2, such as the degree of conversion and the crosslinking density [16]. However, not enough is known about such effects on the surface properties of resins which have clearer shades.

Therefore, this study aimed to analyze the effect of two LEDs on the DC of a composite resin for bleached teeth under the influence of adhesive systems used as modeling liquid. The null hypotheses tested were: 1) the use of an adhesive system as modeling liquid does not change the DC of a composite for bleached teeth; and 2) the use of monowave or polywave LEDs does not change the DC of a composite for bleached teeth submitted to the use of adhesive systems as modeling liquid.

\section{MATERIAL \& METHODS}

\section{samples \\ Experimental design and preparation of}

This study employed a $2 \times 3$ factorial design, as two LEDs and three groups of adhesive systems used as modeling liquid were analyzed. The analyzed response was the percentage (\%) of DC.

A commercial brand of composite resin IPS Empress Direct resin [ED] (Ivoclar, Vivadent, AG, Schaan, Liechtenstein) in BL-L shade was used. The treatments were: 1) Type of adhesive used as modeling liquid (Adper Single Bond 2; the bond component of Adper Scotchbond MultiPurpose; or no adhesive system was used as modeling liquid in the control group); and 2) Type of LEDs (Bluephase, polywave; and Coltolux, monowave).

A total of 60 samples $(n=10)$ of ED composite (Ivoclar Vivadent) in the BL-L shade were prepared into circular teflon molds $(5 \mathrm{~mm}$ diameter $\times 2 \mathrm{~mm}$ height). The composite was inserted in a single increment and adapted to the mold with a Thompson no. 1 spatula (Thompson Dental Products, Houston, TX, USA) under temperature control at $22^{\circ} \mathrm{C}$. Next, the composite surface was modeled using flat composite brush no. 1021 (Hot Spot Design, Cugy, Switzerland) and coated with one drop of SB or MP, which were the adhesive systems used as modeling liquid. No adhesive system was used as modeling liquid in the control group (CT).

One drop of the material was applied to the brush head to coat the brush with adhesive 
systems and excess was removed by stroking each side of the brush onto a glass plate for 3 seconds. Sculpting consisted of three sweeping motions of the adhesive-dampened instrument against each half of the circular composite surface (a total of six motions for each sample) [16].

A microscopic slide was pressed onto the sample and the composite was photoactivated for 20 seconds using polywave Bluephase G2 LED (Ivoclar Vivadent, Liechtenstein) or monowave Coltolux LED (Coltène Whaledent, Altstätten, Switzerland), both with a light intensity of $1200 \mathrm{~mW} / \mathrm{cm}^{2}$ (according to the manufacturer's instructions) and previously measured in a portable radiometer RD-7 (ECEL, Ribeirão Preto, SP, Brazil) in order to ensure adequate power. Then the sample was removed from the mold and the excess edges were removed with a no. 15 scalpel blade. The base was scratched with a 1012 diamond drill tip to differentiate it from the surface to be analyzed. The samples were separately placed into properly identified eppendorfs and stored in a light-free amber vessel in conservation at $37^{\circ} \mathrm{C}$ in an incubator for a period of 24 hours until the DC analyzes were performed.

The compositions of the materials used in this study are listed in Table 1.

Table 1 - Materials used in this study

\begin{tabular}{|c|c|c|c|}
\hline Material & Composition & Manifacturer & Lot \\
\hline $\begin{array}{l}\text { IPS Empress } \\
\text { Direct (BL-L) }\end{array}$ & $\begin{array}{c}\text { UDMA (10-25\%), Ytter- } \\
\text { bium trifluoride (3-10\%), } \\
\text { Tricyclodocane dimethanol } \\
\text { dimethacrylate (3-10\%), } \\
\text { BisGMA (2.5-3\%). }\end{array}$ & $\begin{array}{l}\text { Ivoclar } \\
\text { Vivadent, } \\
\text { AG, Schaan, } \\
\text { Liechtenstein }\end{array}$ & $\begin{array}{c}\text { S10171 } \\
\text { T28435 }\end{array}$ \\
\hline $\begin{array}{l}\text { Adper } \\
\text { Scotchbond } \\
\text { Multi-Purpo- } \\
\text { se Adhesive } \\
\text { (bond) }\end{array}$ & $\begin{array}{c}\text { BisGMA (60-70\%), HEMA } \\
(30-40 \%), \text { triphenyl anti- } \\
\text { mony (« 1\%) }\end{array}$ & $\begin{array}{l}\text { 3M ESPE, St. } \\
\text { Paul, MN, USA }\end{array}$ & N571827 \\
\hline $\begin{array}{l}\text { Adper } \\
\text { Single Bond } 2 \\
\text { Adhesive }\end{array}$ & $\begin{array}{l}\text { Ethyl alcohol (25-35\%), } \\
\text { BisGMA (10-20\%), UDMA } \\
\text { (1-5\%), HEMA (5-15\%), } \\
\text { glycerol 1,3-dimethacrylate } \\
\text { (5-10\%), nanofiller (10- } \\
\text { 20\%), copolymer of acrylic } \\
\text { acid and itaconic (5-10\%), } \\
\text { water («5\%), diphenylodo- } \\
\text { nium hexafluorophosphate } \\
\text { («0.5\%), EDMAB («0.5\%). }\end{array}$ & $\begin{array}{l}\text { 3M ESPE, St. } \\
\text { Paul, MN, USA }\end{array}$ & N508311 \\
\hline
\end{tabular}

Legend:

UDMA: Diurethane dimethacrylate

BisGMA: Bisphenol A diglycidyl ether dimethacrylate

HEMA: 2-hydroxyethyl methacrylate

Nanofiller: Silane treated silica

EDMAB: Ethyl 4-dimethylaminobenzoate

\section{DEGREE OF CONVERSION}

DCreadingswereperformed using theFourier transform infrared spectroscopy (FTIR) technique. The samples were inserted on the spectrometer and evaluated on the top surface (which received the adhesive system layer) on a Spectrum 100 FTIR spectrometer coupled to an attenuated total reflection device (ATR) (PerkinElmer, Shelton, CT, USA). The DC parameters used 10 scans and wavenumber related to $1 / \lambda$, which creates a graph for observing the peaks at 1608 and 1638 $\mathrm{cm}^{-1}$; characteristic of the aromatic vinyl bonds of bisphenol and aliphatic bonds of the methacrylate functional group, respectively. Unpolymerized samples of the composite resin used were also evaluated. The DC (\%) was calculated using the following equation:

DC $(\%)=100 \times(1-[$ Rpolymerized/ Runpolymerized])

Where: $\mathrm{R}$ represents the ratio between the absorbance peak at $1638 \mathrm{~cm}^{-1}$ to $1608 \mathrm{~cm}^{-1}$. [17]

\section{STATISTICAL ANALYSIS}

The data were statistically analyzed by twoway analysis of variance (ANOVA) and Tukey's test $(p<0.05)$ at a significance level of $5 \%$ in ASSISTAT 7.7 beta software.

\section{RESULTS}

There was no statistically significant differences between LEDs, neither in the interaction between adhesive system used as modeling liquid and LEDs ( $p>0.05)$. However, there was statistically significant differences among adhesive systems ( $\mathrm{p}<$ 0.05). However, there was a statistically significant increase in the DC for the two tested adhesive systems concerning the control group for both Bluephase and Coltolux LEDs, with the highest DC values obtained when SB was applied ( $\mathrm{p}<0.05$ ). Comparisons between groups are listed in Table 2. 
Table 2 - Means (standard deviations) of the degree of conversion (\%) according to the kind of LED and adhesive system used as modeling liquid.

\begin{tabular}{|ccc|} 
& \multicolumn{2}{c|}{ LEDs } \\
\hline Adhesive system & Bluephase & Coltolux \\
\hline None & $40.7780(12.6) \mathrm{cA}$ & $40.1323(14.3) \mathrm{CA}$ \\
\hline Adper Single Bond 2 & $80.1376(3.4) \mathrm{aA}$ & $77.5782(7.3) \mathrm{aA}$ \\
\hline $\begin{array}{c}\text { Adper Scotchbond } \\
\text { Multipurpose }\end{array}$ & $54.9736(15.2) \mathrm{bA}$ & $55.4896(8.9) \mathrm{bA}$ \\
\hline
\end{tabular}

Means followed by distinct upper case letters denote statistically significant differences between the kinds of LEDs for the same dental adhesive used as modeling liquid $(p<$ 0.05). Means followed by lower case letters denote statistically significant differences between dental adhesive used as modeling liquid for the same kind of LED $(p<0.05)$.

\section{DISCUSSION}

The first null hypothesis tested in this study was rejected since the use of both tested adhesive systems increased the DC of the composite compared to the control group (Table 2).

It is known that the adhesive systems used have 2-hydroxyethyl methacrylate (HEMA) in their compositions, which is a hydrophilic monomer widely used in commercial adhesive systems and which promotes a higher DC [18], which may have contributed to the increase in DC compared to the control group. In addition, the presence of urethane dimethacrylate monomer (UDMA) in the SB adhesive system can explain the higher value presented in the DC, since this monomer has a flexible structure with less hydrogen bonds than BisGMA, thereby increasing the DC [19-20]. On the other hand, the higher amount of BisGMA monomer in the MP composition would explain the lower DC values of this adhesive in comparison to SB, since it has an epoxy central portion and unsaturated acrylic radicals at its extremities, presenting high molecular weight $(512 \mathrm{~g} / \mathrm{mol})$, high viscosity (500,000-800,000 MPa), low mobility and low DC at ambient temperature $[19,21]$.

In contrast, the second null hypothesis was accepted, since there was no statistically significant difference between the DC values when using second- or third-generation of LEDs (Table 2).
The literature reveals a probable inadequate correlation between the absorption spectrum of alternative photoinitiators and the emission spectrum of photoactivation units. Due to their short emission spectrum, second-generation LEDs may not activate some alternative photoinitiators present in the composite $[6,8]$, consequently compromising the polymerization reaction and decreasing the DC.

Therefore, as the present study has analyzed a composite for bleached teeth in BL-L shade that hypothetically should contain alternative photoinitiators to CQ, a greater effectiveness of the third generation LED was expected. Nevertheless, this fact was not confirmed, leading to the assumption of the presence of CQ in the composition of the composite in question (data not informed by the manufacturer). The unavailability of details about the chemical composition of the products by the manufacturers is a limitation of the study, because to know what kind of photoinitiators were used would help understand their behavior in relation to the type of LED.

Another possibility would be that the ultraviolet LEDs (third generation) accountable for the alternative photoinitiators activation (which have their maximum absorption at the light spectrum of $320-400 \mathrm{~nm}$ ) [22] should be distributed in the tips of the third generation Bluephase G2 LED (Ivoclar Vivadent, Liechtenstein) in such a way that there is no direct interaction with the alternative photoinitiators present in the tested adhesives during photoactivation [23].

Therefore, it is observed that there is a need for information related to the type of photoinitiators present in the composition of the composites by the manufacturers in order to guide the clinician's choice of suitable LED for correct photoactivation of these materials without implications on the longevity of the restorations.

\section{CONCLUSION}

The use of adhesive systems as modeling liquid in the composite insertion and sculpture technique increased the DC on the surface of a composite for bleached teeth, regardless of the light emitting diodes (LEDs) being either monowave or polywave. 


\section{REFERENCES}

1. Gouveia THN, Theobaldo JD, Vieira-Junior WF, Lima DANL, Aguiar FHB Esthetic smile rehabilitation of anterior teeth by treatment with biomimetic restorative materials: a case report. Clin Cosmet Inestiq Dent. 2017 May;9:27-31

2. Ferracane JL Correlation between hardness and degree of conversion during the setting reaction of unfilled dental restorative resins. Dent Mater. 1985 Feb;1(1):11-4.

3. Calixto LR, Lima DM, QueirozRS, Rastelli ANS, Bagnato VS, Andrade MF.Curing depth of composite resin light cured by led and halogen light-curing units. Laser Phys. 2008 Nov;18(11):1365-9.

4. Khalichi P,Singh J, Cvitkovitch DG, Santerre JP. The influence of triethylene glycol derived from dental composite resins on the regulation of Streptococcus mutans gene expression. Biomaterials. 2009 Feb;30(4):452-9

5. Villarroel M,FahI N, de Sousa AM, de Oliveira OB JR. Direct esthetic restorations based on translucency and opacity of composite resins. J Esthet Restor Dent. 2011Apr;23(2):73-88

6. Arikawa H, Takahashi H, Kanie T, Ban S. Effect of various visible light photoinitiators on the polymerization and color of light-activated resins. Dent Mater J.2009 Jul,28(4):454-460.

7. de Oliveira DC, Rocha MG, Gatti A, Correr AB, Ferracane JL, Sinhoret MA. Effect of different photoinitiators and reducing agents on cure efficiency and color stability of resin-based composites using different led wavelengths. J Dent. 2015Dec;43(12):1565-72.

8. Cardoso KA, Zarpellon DC, Madruga CF, Rodrigues JA, Arrais CA. Effects of radiant exposure values using second and third generation light curing units on the degree of conversion of a lucirin-based resin composite.J Appl Oral Sci. 2017 Mar-Apr;25(2):140-146.

9. Albuquerque PPA, Moreira AL, Moraes RR, Cavalcante LM, Schneider LFJ.Color stability, conversion, water sorption and solubility of dental composites formulated with different photoinitiator systems. J Dent. 2013 Aug;41(3):e67-e72.

10. Santini A, Miletic V, Swift MD, Bradley M. Degree of conversion and microhardness of TPO-containing resin-based composites cured by polywave and monowave LED units. JDent. 2012 Jul|40(7):577-84.

11. Obici AC, Sinhoreti MA, Frollini E, Sobrinho LC, Consani S. Degree of conversion of Z250 composite determined by fourier transform infrared spectroscopy: comparison of techniques, storage periods and photo-activation methods. Mat Res. 2004 0ct-Dec;7(4):605-10.
12. Dunn WJ, Strong TC.Effect of alcohol and unfilled resin in the incremental buildup of resin composite. Quintessence Int.2007 Jan;38(1):e20-6.

13. Barcellos DC, Pucci CR, Torres CR, Goto EH, Inocencio AC. Effects of resinous monomers used in restorative dental modeling on the cohesive strength of composite resin. J Adhes Dent. 2008 0ct;10(5):351-4.

14. Perdigão J, Gomes G. Effect of instrument lubricant on the cohesive strength of a hybrid resin composite. Quintessence Int 2006 Sep;37(8):621-625.

15. MünchowEA, Sedrez-Porto JA, Piva E, Pereira-Cenci T,Cenci MS. Use of dental adhesives as modeler liquid of resin composites. Dent Mater.2016 Apr;32(4):570-577.

16. de Paula FC, Valentim RdeS, Borges BC, Medeiros MC, de Oliveira RF, da Silva $A 0$. Effect of instrument lubricants on the surface degree of conversion and crosslinking density of nanocomposites. J Esthet Restor Dent. 2016 MarApr;28(2)85-91.

17. da SilvaEM, Poskus LT, Guimarães JG. Influence of light-polymerization modes on the degree of conversion and mechanical properties of resin composites: a comparative analysis between a hybrid and a nanofilled composite. Oper Dent. 2008 May-Jun;33(3):287-93.

18. Collares FM, OgliariFA, Zanchi CH, Petzhold CL, PivaE, Samuel SM. Influence of 2-hidroxyethyl metacrylate concentration on polymer network of adhesive resin. J Adhes Dent. 2011 Apr;13(2):125-9.

19. Gajewski VE, Pfeifer CS, Fróes-Salgado NR, Boaro LC, Braga RR. Monomers used in resin composites: degree of conversion, mechanical properties and water sorption/solubility.Braz Dent J.2012Sept-0ct;23(5):508-514.

20. Vasudeva G. Monomer systems for dental composites and their future: a review. J Calif Dent Assoc. 2009 Jun;37(6):389-398.

21. Ferracane JLC Current trends in dental composites. Crit Rev Oral Biol Med. 1995;6(4):302-18.

22. Giorgi MC, Aguiar FH, Soares LE, Martin AA, Liporoni PC, Paulillo LA. Does an additional UV LED improve the degree of conversion and Knoop hardness of light-shade composite resins? Eur J Dent. 2012 Oct;6(4):396-401.

23. Harlow JE, Rueggeberg FA, Labrie D, Sullivan B, Price RB. Transmission of violet and blue light through conventional (layered) and bulk cured resin-based composites. JDent. 2016 0ct;53(1):44-50.

\section{Ana Margarida dos Santos Melo}

(Corresponding address)

35 President Juscelino Kubitschek street

Natal-RN 59069-170 - Brazil.

E-mail: anamdsmelo@gmail.com

Date submitted: 2018 Feb 22

Accept submission: 2018 Jun 05 